\title{
A kortikoszteroidtartalmú szemcseppek alkalmazása gyermekkori allergiás szembetegségek kezelésében
}

\author{
Csorba Anita dr. ${ }^{1}$ - Soproni Anna dr. ${ }^{2}$ - Maneschg Otto dr. ${ }^{1}$ \\ Nagy Zoltán Zsolt dr. ${ }^{1}$ - Szamosi Anna dr. ${ }^{1}$ \\ 'Semmelweis Egyetem, Általános Orvostudományi Kar, Szemészeti Klinika, Budapest \\ ${ }^{2}$ Soproni Anna Szemészeti Magánrendelő, Budapest
}

\begin{abstract}
Napjainkban az allergiás megbetegedések száma folyamatosan emelkedik. Az atópiás betegeknél gyakran jelentkeznek szemet érintő allergiás megbetegedések (szezonális és perennialis allergiás kötőhártya-gyulladás, vernalis keratoconjunctivitis, atópiás keratoconjunctivitis, óriás papillás kötőhártya-gyulladás, kontaktblepharoconjunctivitis). Az allergiás szembetegségek kezelésében szemcsepp formájában használt gyógyszerek közé tartoznak az antihisztaminok, a hízósejtmembrán-stabilizálók, a kettős támadáspontú szerek, az érösszehúzók és a kortikoszteroidok. Egyes esetekben szisztémásan antihisztaminok is használhatók. A kezelés látszólag egyszerú, a helytelen terápia azonban - szélsőséges esetben - akár látásvesztéshez is vezethet. A szemtünetek enyhítésében a kortikoszteroidok kiváló gyógyszernek számítanak, de használatuk jelentős figyelmet igényel mind a kezelőorvos, mind a beteg részéról, hiszen súlyos mellékhatásaik vannak. Ezek közül a látást leginkább veszélyeztető elváltozások a szteroidindukált szürke hályog és a még súlyosabb szteroidindukált glaukóma. Felnőttek körében e két kórkép jellemzőit, előfordulási gyakoriságát és kockázati tényezőit részletesen tanulmányozták, ellenben gyermekek esetében igen kevés irodalmi adat áll rendelkezésünkre a szteroidszemcsepp mellékhatásaival kapcsolatosan. Az eddigi tanulmányok alapján gyermekeknél sokkal nagyobb arányban alakulnak ki mellékhatások a szteroidterápia mellett, mint felnőttek körében.

Orv Hetil. 2019; 160(9): 329-337.
\end{abstract}

Kulcsszavak: allergiás kötőhártya-gyulladás, vernalis keratoconjuntivitis, szteroidindukált glaukóma, gyermekek

\section{Application of corticosteroid eye drops for allergic eye diseases in children}

The prevalence of allergic diseases has been increasing recently. Allergy has various symptoms. Allergic eye diseases (seasonal and perennial allergic conjunctivitis, vernal keratoconjunctivitis, atopic keratoconjunctivitis, giant papillary conjunctivitis, contact blepharoconjunctivitis) are common in atopic patients. Treatment options for allergic conjunctivitis include local and systemic antihistamines, mast cell stabilizers, dual-action agents, vasoconstrictors and corticosteroids. Treatment seems easy, but inappropriate therapy - in extreme cases - can lead to vision loss. Corticosteroid eyedrops provide effective relief of symptoms, however, their use is limited due to their severe side effects. Both steroid-induced cataract and steroid-induced glaucoma are dangerous for vision. The characteristics, frequency and risks of these side effects have been studied widely in adults, but there are very few studies focused on children. According to the present studies, the side effects of topically administered corticosteroids appear more often in children than in adults.

Keywords: allergic conjunctivitis, keratoconjunctivitis vernalis, steroid-induced glaucoma, children

Csorba A, Soproni A, Maneschg O, Nagy ZZs, Szamosi A. [Application of corticosteroid eye drops for allergic eye diseases in children]. Orv Hetil. 2019; 160(9): 329-337.

(Beérkezett: 2018. július 30.; elfogadva: 2018. szeptember 2.) 


\section{Rövidítések}

$\mathrm{AKC}=($ atopic keratoconjunctivitis $)$ atópiás kötóhártya-gyulladás; $\mathrm{CBC}=($ contact blepharoconjunctivitis $)$ kontakt allergiás kötőhártya-gyulladás; DMS = (dexamethasone) $)$ dexametazon; FDA = (U.S. Food and Drug Administration) az Egyesült Államok Élelmiszer-biztonsági és Gyógyszerészeti Hivatala; FLM $=$ (fluorometholone $)$ fluorometolon; GPC $=$ (giant papillary conjunctivitis) óriás papillás kötőhártya-gyulladás; IOP = (intraocular pressure) szemnyomás; $\mathrm{LE}=$ (loteprednol etabonate) loteprednol-etabonát; MGD $=$ (Meibomian gland dysfunction) Meibom-mirigy-diszfunkció; PA = (prednisolon acetate) prednizolon-acetát; $\mathrm{PAC}=$ (perennial allergic conjunctivitis $)$ perennialis allergiás kötőhártya-gyulladás; $\mathrm{SAC}=($ seasonal allergic conjunctivitis) szezonális allergiás kötőhártya-gyulladás; SIG = (steroid-induced glaucoma) szteroidindukált glaukóma; VKC (vernal keratoconjunctivitis) vernalis keratoconjunctivitis

\section{Az allergiás szembetegségek típusai, klasszifikációja}

A szem leggyakoribb túlérzékenységi reakciója az allergiás kötőhártya-gyulladás [1]. Legjellemzőbb tünete a szemviszketés, melyhez könnyezés, vörhenyes kötőhártya, fényérzékenység és idegentest-érzés társulhat [2]. Érintett lehet a szemhéj, valamint a súlyosabb formák szövődményeként a szaruhártya is. A tünetek általában kétoldaliak, azonban az egyik oldal érintettsége a másikénál súlyosabb lehet.

Leggyakoribb formája a szezonális allergiás kötőhártya-gyulladás (SAC) [1]. Tavasz és ősz vége között jelentkezik, a levegóben lévő magas pollenkoncentráció következtében. Szemviszketés, könnyezés, a szem vörössége, a duzzadt szemhéj, a kötőhártya-ödéma (chemosis), a tarsalis kötőhártyán megjelenő kis papillák és víztiszta exsudatum jellemzi [3]. A perennialis allergiás kötőhártya-gyulladás (PAC) ugyanilyen tüneteket okoz, de az allergének (például állatszőr, poratka) folyamatos jelenléte miatt krónikus lefolyású. Szezonálisan gyakori a fellángolás [1] (1.ábra). Maradandó látásromlást nem okoznak, de az életminőséget nagyban ronthatják [4].

Ritkább kórkép a vernalis keratoconjunctivitis (VKC), mely általában 4 és 12 év közötti fiúknál jelentkezik [5]. Krónikus lefolyású, igen intenzív viszketés jellemzi, melyet könnyezés, fényérzékenység, chemosis, a szem vörössége, illetve bó, fibrines váladékozás kísér. Nagyon jellegzetesek a felső tarsalis conjunctiván az utcakőrajzolathoz hasonlóan elhelyezkedő óriás papillák (2. ábra), melyek mechanikailag sérthetik a corneát, hámhiányokat és ennek következtében fekélyeket okozva [6]. A limbusban áttetsző nodulusok alakulnak ki, melyeken fehér pettyek (Horner-Trantas-csomók) (3. ábra) vannak [4]. A tünetek tavasszal exacerbálódnak, ősszel javulnak.

$\mathrm{Az}$ atópiás keratoconjunctivitis (AKC) krónikus lefolyású, és nagyon gyakori az atópiás anamnézis [1]. Vezető tünete a szemhéjak ekcémás elváltozása, melyet a szem viszketése, égố érzése és könnyezés kísér. Jellemző a Meibom-mirigyek diszfunkciója (MGD). Érintett lehet

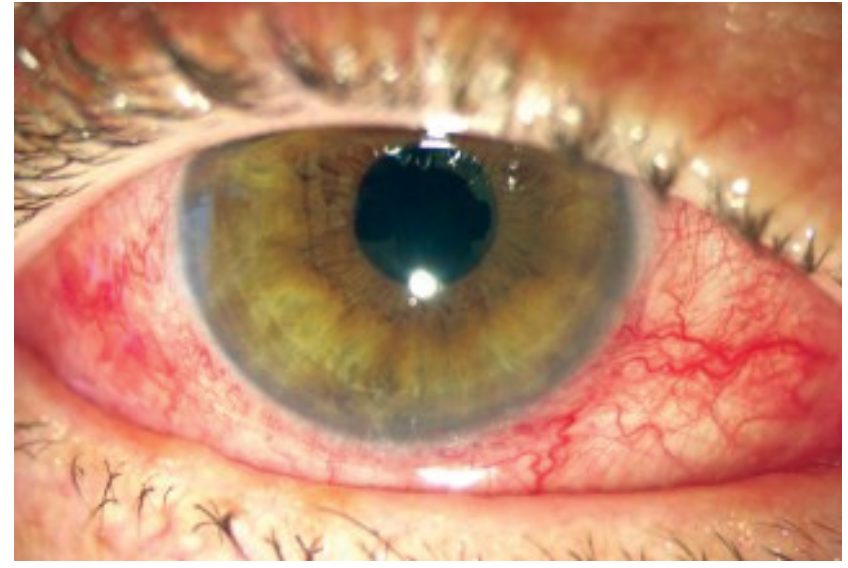

1. ábra $\mid$ Perennialis conjunctivitis. Szezonális fellángolás (a Semmelweis Egyetem Szemészeti Klinikájának képgyújteményéből)

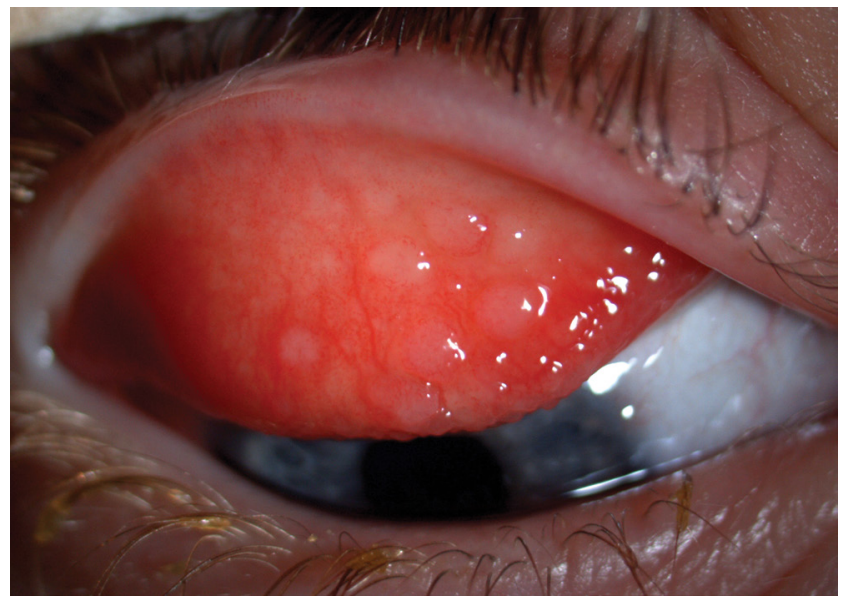

2. ábra

Óriás papillák a felső szemhéji kötőhártyán (a Semmelweis Egyetem Szemészeti Klinikájának képgyűjteményéből)

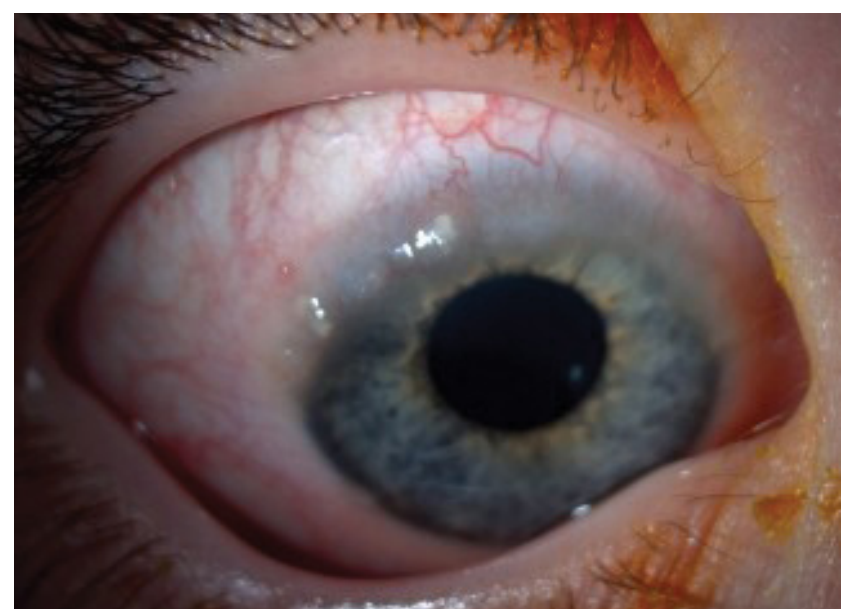

3. ábra

Horner-Trantas-csomók a limbusban (a Semmelweis Egyetem Szemészeti Klinikájának képgyújteményéből)

a szaruhártya, valamint megjelenhetnek a Horner-Trantas-csomók [1]. Hosszabb idő után a kötőhártya fibroticusan átalakulhat [6]. 
Az óriás papillás kötőhártya-gyulladás (GPC) valamilyen idegen test (például kontaktlencse, múszem, varrat a szemben) hatására fellépő túlérzékenységi reakció [1]. A tünetek között szemviszketés, könnyezés, idegentestérzés, fokozott váladéktermelődés figyelhető meg, melyet a kötőhártya ödémája és vörhenye követhet. A felső szemhéji kötőhártyán papillaris hypertrophia jelentkezik [7] (4. ábra).

A kontaktblepharoconjunctivitis (CBC) valamilyen irritáló anyag (például lokálisan alkalmazott gyógyszerek, tartósítószerek, kozmetikumok) szemhéjra vagy kötőhártyára jutása miatt kialakuló túlérzékenységi reakció

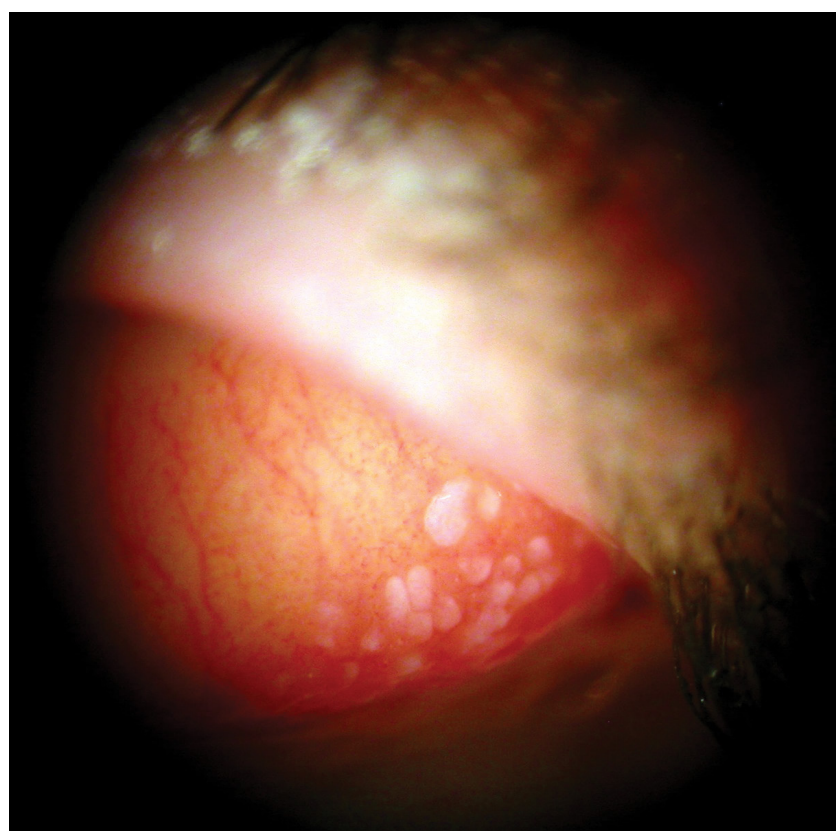

4. ábra

GPC: papillaris hypertrophia a felső szemhéji kötőhártyán (a Soproni Anna Szemészeti Magánrendelő képgyűjteményéből)

GPC = óriás papillás kötőhártya-gyulladás

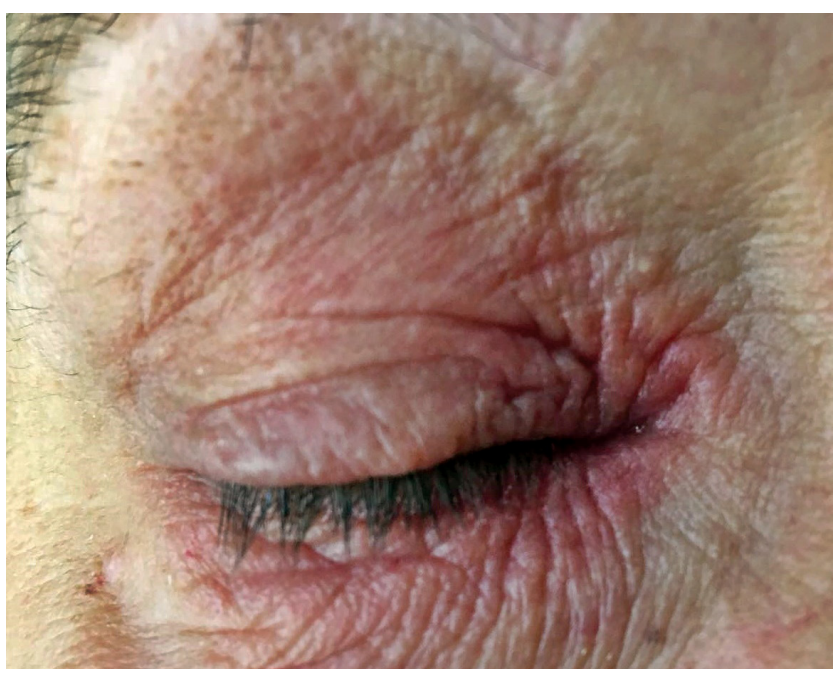

Kozmetikai krém használatát követő periocularis dermatitis (a Soproni Anna Szemészeti Magánrendelő képgyújteményéből)
[3]. Vezető tünete a szem és a szemhéj erős viszketése, égó érzése. A szemhéj és a kötőhártya ödémássá, vörhenyessé válhat (5. ábra), a conjunctiván papillák is megjelenhetnek [4].

A szemet érintő allergiás megbetegedéseket a tünetek időtartama (intermittáló/perzisztáló) és súlyossága (enyhe/közepes/súlyos) alapján osztályozhatjuk. Intermittáló a megbetegedés, ha a tünetek (viszketés, vörheny) fennállása nem éri el a 4 hetet vagy a heti 4 napot. Perzisztáló esetben a tünetek 4 hétnél hosszabb ideig tartanak, vagy egy hét alatt több, mint 4 napon jelennek meg. Enyhe megbetegedés esetén a páciensnek nincs sem látászavara, sem kínzó tünete, így ezek nem akadályozzák a mindennapi tevékenység végzésében, nem zavarják a pihenést vagy a fizikai aktivitást, nem romlik az iskolai vagy munkahelyi teljesítmény. Közepesen súlyos esetben a fenti tünetek közül egy mindenképpen, míg súlyos esetben kettő vagy akár több is megvan [7].

\section{Terápiás lehetőségek}

A páciens gyógyszeres kezelésének megkezdése előtt minden esetben az úgynevezett nem gyógyszeres lehetőségeket érdemes számba venni. Ha csak egy mód van rá, a betegnek kerülnie kell a klinikailag releváns allergéneket. Ajánlhatjuk neki, hogy amikor a szabadban tartózkodik, viseljen védő- vagy napszemüveget. Ezzel megelőzhető, hogy például az erôs szél vagy a por irritálja a szemét [3]. A viszketést csökkentheti a hideg vizes borogatás, valamint a naponta többször (például 2-4-szer) cseppentett tartósítószer-mentes múkönny [1]. Az óriás papillás és a kontakt allergiás kötőhártya-gyulladásoknál elsődleges a kiváltó ok kiiktatása [5].

A lokálisan alkalmazandó antiallergiás szerek széles választéka áll rendelkezésre az allergiás kötőhártya-gyulladás kezelésére: az antihisztaminok közül a második generációs szerek (levokabasztin, emedasztin, azelasztin) használata javasolt, hiszen e szerek - az első generációs hatóanyag-tartalmúakkal (feniramin, antazolin) ellentétben - hosszabb ideig (4-6 óra) hatnak, és cseppentéskor nem okoznak égő fájdalmat, így jól tolerálhatók [7]. Napi négyszeri cseppentése javasolt [8]. A lokális antihisztaminok érösszehúzó szerekkel vagy hízósejtmembrán-stabilizálókkal kombinációban is alkalmazhatók [3]. Antihisztamint egyéb allergiás tünetek (például tüsszögés, orrfolyás) fennállása esetén - a lokális terápia mellett - szájon át is adhatunk, ilyenkor is előnyben részesítve a második generációs készítményeket (loratadin, dezloratadin, cetirizin), mert ezek szedatív mellékhatása - az első generációs szerekével összevetve - elhanyagolható [7].

A hízósejtmembrán-stabilizáló szerek (nátrium-kromoglikát, nedokromil-nátrium, lodoxamid, spaglumátnátrium) gátolják a hízósejtek degranulációját. Használatuk az allergénexpozíció előtt minimum két héttel, napi 3-4-szer cseppentve, profilaktikusan megkezdhető [4, 9].

A kettős támadáspontú készítményeknek (azelasztin, epinasztin, ketotifen, olopatadin) mint antihisztaminok- 
nak az előnyük, hogy azonnal enyhítik a tüneteket, membránstabilizáló tulajdonságuk révén viszont hosszú ideig tartó hatást biztosítanak [10], így elég naponta kétszer cseppenteni belőlük [4].

Az érösszehúzó szerek gyorsan csökkentik a kötőhártya vérteltségét és ödémáját. Cseppentésük égő, szúró fájdalmat okoz, hosszú távon pedig szemszárazság, hámkárosodás léphet fel [9], ezért használatuk nem ajánlott [11].

$\mathrm{Az}$ allergiás szembetegségek kezelésében a kortikoszteroidtartalmú szemcseppek nagyon hatékonyak, ennek ellenére - potenciálisan veszélyes mellékhatásaik (szürke hályog, másodlagos glaukóma) miatt - nem elsőként választandó szerek [7]. Használatukra csak akkor kerül sor, ha az egyéb antiallergiás gyógyszerek nem csökkentik a tüneteket. Közepesen súlyos állapotban elsőként választandó hatóanyagok az úgynevezett „soft” szteroidok (fluorometolon, loteprednol-etabonát) [4]. A hagyományos szteroidokkal ellentétben e szerek használata mellett ritkábban alakulnak ki mellékhatások [12], de a gyulladásos tüneteket kevésbé hatékonyan csökkentik [7]. A hagyományos szteroidokat (prednizolon, dexametazon) csak súlyos gyulladás esetén indokolt adni [4], hiszen ezek alkalmazása mellett gyakrabban kell számítani szteroid okozta mellékhatásokra [13]. Az akut fázis kontrollálása után a terápiát abba kell hagyni, és azt csak egyéb antiallergiás szerekkel (membránstabilizálók, antihisztaminok) szabad tovább folytatni. A rendszeres szemfenék- és réslámpás vizsgálat, valamint a szemnyomás (IOP) mérése mind a terápiás hatások értékelése céljából, mind a mellékhatások időben történő észlelése érdekében elengedhetetlen [4].

\section{Új lehetőségek, alternatívák}

A közelmúltban egy új, az FDA által jóváhagyott kortikoszteroid, a loteprednol-etabonát (LE) került be az allergiás kötőhártya-gyulladás kezelési eszköztárába. A LE módosított szerkezetű kortikoszteroid, aminek köszönhetően a szövetekkel való érintkezés után viszonylag gyorsan lebomlik. A ketont tartalmazó hagyományos szteroidokkal szemben lényegesen kevesebb mellékhatása van: észtertartalmú oldallánca és a szemlencse fehérjéi között nem játszódik le kémiai reakció, így alkalmazása mellett szürke hályog kialakulására nem kell számítanunk. Szemnyomásemelő hatása is sokkal kisebb [14].

A LE hatásait az allergiás conjunctivitis kezelésében számos tanulmány vizsgálta. Ezek alapján a LE meglehetősen biztonságos szernek bizonyult. Leírták, hogy egy hónapnál rövidebb és egy hónapnál hosszabb távú használata is veszélytelen, igen kevés esetben okoz szignifikáns IOP-emelkedést [13]. Az allergiás conjunctivitis sok esetben nehezen kezelhető formájában, a VKC kezelésében is ígéretesnek mutatkozik. Öner és mtsai VKCben szenvedő gyermekeknél 4 héten át vizsgálták a fluorometolon (FML), a prednizolon-acetát (PA) és a loteprednol-etabonát hatásait. Adataik alapján a LE ugyanolyan hatékonyan képes enyhíteni a tüneteket, mint a PA, ebben a tekintetben viszont a FML hatása jelentősen elmarad a másik két szeréhez képest. A PA adása már a harmadik naptól szemnyomás-emelkedéssel járt, míg FML és LE esetén ez a hatás még négy hét elteltével sem jelentkezett. Az eredmények azt tükrözik, hogy a VKC kezelésében a LE igen hatékonyan, de mellékhatások nélkül képes csökkenteni a tüneteket [14]. Magyarországon loteprednol-etabonátot tartalmazó szemészeti készítmény egyelőre nem kapható.

Az eddigiek mellett fontos megemlíteni a kalcineuringátlókat (ciklosporin $\mathrm{A}$, takrolimusz) mint az allergiás szembetegségek kortikoszteroidterápiájának alternatíváit. A szemészeti allergológiában „szteroidspóroló” szereknek is nevezik óket, miután a súlyos tünetekkel járó allergiás szembetegségekben a kortikoszteroidokhoz hasonló hatékonysággal, de mellékhatások nélkül alkalmazhatók. A szemnyomást nem befolyásolják, szürke hályogot nem okoznak, jól tolerálható szerek. Az eddigi tanulmányok szerint a ciklosporin $0,05-2 \%$-os, a tacrolimusz 0,005-0,1\%-os koncentrációban biztonságos, és komolyabb mellékhatások nélkül [15] is hatékonynak bizonyul. Alkalmazásukra súlyos, krónikus, elhúzódó kortikoszteroidterápiát igénylő állapotokban kerülhet sor, kiváltva a kortikoszteroid használatát [16]. Az eddigi adatok alapján a $0,05 \%$-os ciklosporinszemcsepp napi 2-4-szer cseppentve jelentősen csökkentette az allergiás szemtüneteket VKC-ben és AKC-ben szenvedő pácienseknél [17, 18]. Európában a kalcineuringátlók használata az allergiás conjunctivitis terápiájában jelenleg „off label” kezelésnek minősül. Az FDA által jóváhagyott egyetlen, ciklosporint tartalmazó szemészeti készítmény a száraz szem kezelésében alkalmazható 0,05\%-os ciklosporinszemcsepp. Középsúlyos vagy súlyos atópiás keratoconjunctivitis esetén 0,03\%-os tacrolimuszt tartalmazó krém napi kétszeri használata javasolt a szemhéjelváltozások kezelésére [19], ilyen készítmény azonban Magyarországon egyelőre nem érhető el.

VKC kezelése során a lokális szemcseppen kívül más formában is alkalmazhatunk kortikoszteroidot. A supratarsalis injekcióban adott triamcinolon-acetonid hatásait vizsgáló tanulmány szerint a kezelés hatékonyan csökkentette az allergiás szemtüneteket, habár itt is leírtak a kezelést követő szemnyomás-emelkedést [20]. Ennél a kórképnél a visszatérő cornealis hámhiányokat okozó óriás papilláknak akár a sebészi eltávolítása is indokolt lehet. Biztonságosnak mondható az a kombinált eljárás, melynek során a papillákat reszekálják, az alapját kriokoagulálják, majd az érintett területet amnionmembránnal fedik. E módszer hatékonyságát jól mutatja, hogy a páciensek 87,5\%-ánál nem recidiváltak a papillák [21].

\section{Útmutató az allergiás szembetegségek gyógyszeres kezeléséhez}

A kezelést a betegség típusától és súlyosságától függően kell megválasztanunk (1. táblázat). SAC és PAC esetén elsőként választandók a lokális antihisztaminok, a hízó- 
1. táblázat | Összefoglaló az allergiás kötőhártya-gyulladásokról és gyógyszeres kezelésükról

\begin{tabular}{|c|c|c|c|c|c|c|}
\hline & SAC & PAC & $\mathrm{VKC}$ & $\mathrm{AKC}$ & GPC & $\mathrm{CBC}$ \\
\hline Időtartam & Szezonális & Idült \pm fellángolások & Idült \pm fellángolások & Idült & $\begin{array}{l}\text { Irritációt } \\
\text { követő́en }\end{array}$ & Irritációt követően \\
\hline Háttér & Atópiás & Atópiás & Atópiás & Atópiás & Nem atópiás & Nem atópiás \\
\hline Szemhéjak & Duzzadt & Duzzadt & Duzzadt & Ekcéma, MGD & - & Bőrpír, viszketés \\
\hline Kötőhártya & $\begin{array}{l}\text { Vörheny, } \\
\text { chemosis, } \\
\text { apró papillák }\end{array}$ & $\begin{array}{l}\text { Vörheny, chemosis, } \\
\text { apró papillák }\end{array}$ & $\begin{array}{l}\text { Belövellt, } \\
\text { óriás papillák }\end{array}$ & $\begin{array}{l}\text { Belövellt, chemosis, } \\
\text { fibrosis }\end{array}$ & $\begin{array}{l}\text { Belövellt, } \\
\text { chemosis, } \\
\text { nagy papillák }\end{array}$ & Belövellt, papillák \\
\hline Limbus & - & - & $\begin{array}{l}\text { Horner-Trantas- } \\
\text { csomók }\end{array}$ & $\begin{array}{l}\text { Horner-Trantas- } \\
\text { csomók }\end{array}$ & - & - \\
\hline Szaruhártya & - & - & $\begin{array}{l}\text { Recidiváló erózió, } \\
\text { fekély }\end{array}$ & $\begin{array}{l}\text { Recidiváló erózió, } \\
\text { fekély }\end{array}$ & - & - \\
\hline \multirow[t]{3}{*}{ Terápia } & \multicolumn{2}{|c|}{$\begin{array}{l}\text { Helyileg antihisztamin/hízósejtmembrán- } \\
\text { stabilizáló/kettős támadáspontú szer } \\
\text { Nagyon súlyos esetben lokális szteroid }\end{array}$} & \multicolumn{2}{|c|}{$\begin{array}{l}\text { Helyileg antihisztamin és/vagy hízósejt- } \\
\text { membrán-stabilizáló és/vagy kettős } \\
\text { támadáspontú szer } \\
\text { Szaruhártya-érintettség esetén lokálisan } \\
\text { szteroid } \\
\text { Nagyon súlyos esetben kalcineuringátló }\end{array}$} & $\begin{array}{l}\text { Lokális } \\
\text { szteroid }\end{array}$ & $\begin{array}{l}\text { Kortikoszteroid- } \\
\text { kenőcs a szemhéjra } \\
+ \\
\text { lokálisan antihiszta- } \\
\text { min }\end{array}$ \\
\hline & \multicolumn{4}{|c|}{ Kísérố allergiás tünetek esetén orális antihisztamin } & \multicolumn{2}{|c|}{ Kiváltó ok megszüntetése } \\
\hline & \multicolumn{6}{|c|}{ Allergén kerülése, hideg vizes borogatás, múkönny } \\
\hline
\end{tabular}

$\mathrm{AKC}=$ atópiás kötőhártya-gyulladás; $\mathrm{CBC}=$ kontakt allergiás kötőhártya-gyulladás; $\mathrm{GPC}=$ óriás papillás kötőhártya-gyulladás; PAC = perennialis allergiás kötőhártya-gyulladás; $\mathrm{SAC}=$ szezonális allergiás kötóhártya-gyulladás; $\mathrm{VKC}=$ vernalis keratoconjunctivitis

sejtmembrán-stabilizálók vagy a kettős támadáspontú szerek. Egyéb allergiás tünetek fennállása esetén szisztémás antihisztaminok is szóba jöhetnek [4]. Csak nagyon súlyos esetekben és a lehető legrövidebb ideig ajánlhatók a lokális szteroidok. Ilyenkor célszerü megoldás lehet a LE [9] naponta négyszeri cseppentése [13].

$\mathrm{Az} \mathrm{AKC}$ és a VKC terápiájában sorrendben szintén az elsők a lokális antihisztaminok, a hízósejtmembrán-stabilizálók vagy a kettős támadáspontú szerek, de ezeket kombinációban alkalmazzuk. Ha a szaruhártya érintetté válik, és bizonyosak lehetünk abban, hogy nincs felülfertőződés, akkor lokális szteroid adására van szükség. Elsőként FML vagy LE ajánlott, ezek hatástalansága esetén térhetünk át hagyományos szteroidra (PA vagy DMS). A gyulladás súlyossága határozza meg az alkalmazott szteroidcsepp adagolását: a mellékhatások elkerülése érdekében a szteroidokat a lehető legalacsonyabb, de még hatásos dózisban és a lehető legrövidebb ideig (3-5 nap) kell alkalmazni [22]. Elhúzódó szteroidterápiát igénylő esetekben kalcineuringátlóra való átállás javasolt [1]. Egyéb allergiás tünetek fennállása esetén a kezelést szájon át szedett antihisztaminnal egészíthetjük ki [4].

GPC esetén elsődleges a kiváltó ok kiiktatása. A kontaktlencse által okozott GPC terápiájában a LE - napi négyszer cseppentve - hatékonyan csökkenti a tüneteket [12].

CBC kezelésekor a kiváltó ok megszüntetése után az akut fázis során kortikoszteroidtartalmú (például hidrokortizon, dezonid) szemkenőcsök ajánlottak a szemhéjra. A viszketés csillapítására lokális antihisztamin adható [16].

\section{A kortikoszteroidtartalmú szemcseppek mellékhatásai}

A szteroidok a szemlencsét károsítva szürke hályogot okozhatnak. A homályok általában a hátsó kéregben, centrálisan kezdődnek és a periféria felé terjednek, jellemzően éles határúak. Gyermekek és diabetesben szenvedők esetén nagyobb valószínúséggel alakulnak ki [3].

A kortikoszteroidok szemnyomást (IOP) emelő hatása és az ennek talaján kialakult másodlagos glaukóma régóta ismert mellékhatás. Armaly vizsgálata alapján a normálpopuláció a szteroidcsepp hatására adott válasza - azaz szemnyomás-emelkedés - alapján három csoportra osztható. Azok az egyének, akiknél a szteroidterápia mellett megemelkedik az IOP, szteroidreszponderek. Elkülöníthetők magas, közepes és alacsony reszponzivitású egyének. A magas reszponzivitású személyeknél a szteroidindukált glaukóma kialakulásának valószínúsége nagy, de a felnőtt populációnak csupán az 5\%-a tartozik ebbe a csoportba. A közepes reszponzivitásúak aránya 35\%, míg az alacsony reszponzivitásúak csoportjába $60 \%$ sorolható [23].

E mellékhatás oka, hogy a szteroidok megváltoztatják a trabecularis hálózat szerkezetét, így a csarnokvíz elvezetésének irányában megnövekszik az ellenállás, és csökken az elfolyás. A lokális kezelés megkezdése után általában három-hat héttel kell számítani az IOP megnövekedésére, habár leírtak olyan esetet is, amelynél az hamarabb, már az első hét után bekövetkezett. A szemnyomásemelő hatás függ a hatóanyag típusától, dózisától, a kezelés időtartamától és az egyéni érzékeny- 
ségtől [24]. Akingbehin tanulmányában a 0,1\%-os dexametazon (DMS) és a $0,1 \%$-os FML hatásait vizsgálták. A DMS-nal kezelt páciensek 62,5\%-ánál alakult ki szignifikáns szemnyomás-emelkedés, míg a FML-nal kezelteknél ugyanez csupán 8,3\% volt. A DMS és a FML IOPemelő hatása között tehát szignifikáns különbség van [25].

A klinikai képet a szemnyomás fokozatos, fájdalmatlan emelkedése jellemzi, ezért a páciens sokáig tünetmentes. A kezdeti szakaszban, amikor még nincs szemfenéki elváltozás, csak a szemnyomásmérés segíthet felismerni a kóros állapotot. A tartósan fennálló magas szemnyomás hatására károsodnak a retinalis ganglionsejtek, elvékonyodik a látóidegfó peremterülete. A primer, nyitott zugú glaukómáéhoz hasonló látótérkiesések alakulnak ki. A kezelés megszűnése után az IOP néhány héten belül normalizálódik, de a látóidegfó és a retinalis károsodások irreverzibilisek.

A szteroidindukált glaukóma (SIG) és a vele járó irreverzibilis károsodások miatt a szteroidok használata igen nagy körültekintést igényel mind a kezelőorvos, mind a páciens részéről. Az IOP rendszeres ellenőrzésével már korai stádiumban diagnosztizálható. Arról, hogy milyen gyakran érdemes szemnyomásmérést végezni, pontos ajánlások nincsenek. Tekintettel a SIG veszélyességére, a kortikoszteroidtartalmú szemcseppet használó páciensek szemnyomását kéthetente ellenőrizni kell [7]. Ha a szembelnyomás emelkedik, a terápiát be kell fejezni. Azoknál az eseteknél, ahol ez nem lehetséges, alacsonyabb dózisú vagy enyhébb hatású szteroidra kell áttérni, és glaukómaellenes terápiát kell kezdeni. Alternatív megoldást jelenthet a kalcineuringátlókra való váltás.

\section{A kortikoszteroidok gyermekszemészeti alkalmazása}

A gyermekek egyéb gyulladásos szemészeti kórképeinél gyakran adunk lokálisan kortikoszteroidot. A felnőttkorban alkalmazott szteroid hatására fellépő glaukómát mint mellékhatást részletesen elemezték, azonban igen kevés a gyermekkorira vonatkozó szakirodalmi adat. Több kutatás szerint gyermekeknél a szteroidindukált szemnyomás-emelkedés markánsabb formában - tehát korábban, magasabb értékekkel és gyakrabban - jelentkezik, mint felnőtteknél. Lam és mtsai rámutattak, hogy a gyermekeknél négy héten át alkalmazott 0,1\%-os DMS gyakrabban és sokkal súlyosabb formában okoz szem- nyomás-emelkedést, mint a felnőtteknél. Armaly beosztása alapján a gyermekek 33\%-a sorolható a magas, 45\%-a a közepes reszponzivitásúak közé, ami igen jelentős különbség. Ebben a tanulmányban azt is leírták, hogy a gyermekeknél az alkalmazott terápia szemnyomásemelő hatása dózis- és korfüggő, a magasabb dózisú gyógyszerhasználat és a fiatalabb életkor mellett ugyanis magasabb szemnyomás alakult ki [23]. Ohji és mtsai tanulmánya alapján szintén jelentős különbség adódott a felnőttek és a gyermekek szteroidreszponzivitása között, itt ugyanis az utóbbiak 82\%-a mutatkozott közepes/magas reszponzivitásúnak. A korfüggó megjelenést Ohji és mtsai is leírták [26]. A dózisdependens megjelenést $\mathrm{Ng}$ és mtsai is kimutatták [27]. Szignifikáns volt a különbség Kwok és $m$ tsai kutatásai alapján is [28]. Ezekben a tanulmányokban a szemnyomásra gyakorolt hatást kancsalságellenes mütétet követő szteroidkezelés mellett vizsgálták.

Egyes tanulmányok szerint a SIG gyermekek és felnőttek közti különbsége a trabecularis hálózat strukturális és funkcionális fejletlensége miatt alakul ki. Remé és mtsai leírása alapján csak nyolcéves kor körül láthatók felnőttkorra jellemző érettséget mutató csarnokzugi képletek. Feltételezések szerint ez a jelenség állhat annak hátterében, hogy szteroidkezelés hatására föként a tízévesnél fiatalabb gyermekeknél jelentkezik markáns IOP-emelkedés [29] (2. táblázat).

\section{Kortikoszteroidok alkalmazása a gyermekszemészeti allergológiában}

A kortikoszteroidok alkalmazása a gyermekkori allergiás szembetegségek egyes eseteiben elkerülhetetlen. Így például, ha a súlyos állapotú vernalis keratoconjunctivitist nem kezelik, akkor jelentősen romlik a gyermek életminősége, egyrészt a betegség akut fázisa alatt jelentkező panaszok, másrészt a szaruhártya-károsodások következtében kialakuló látásvesztés miatt. Noha a kortikoszteroid körültekintő alkalmazásával a betegség szövődményei megelőzhetők, ez a terápia a látást potenciálisan veszélyeztető mellékhatások kialakulásához vezethet. Gyermekek esetén e mellékhatásokra való fogékonyság több, előzőleg megemlített kutatás szerint igen magas, ezért ők a szokásosnál is szorosabb ellenőrzést igényelnek. Mivel a kortikoszteroidokkal gyors és jelentős javulás érhető el, és a beteg panaszait csökkentik, előfordul, hogy a páciensek (saját döntésük révén) az előírtnál magasabb dózisban használják a szert, és ezzel megnövelik a szte-

2. táblázat |A szteroidreszponzivitás aránya gyermekek és felnőttek esetén

\begin{tabular}{|c|c|c|c|c|c|c|}
\hline & Armaly és mtsai & Lam és mtsai & Ohji és mtsai & $\mathrm{Ng}$ és mtsai & Kwok és mtsai & Biedner és mtsai \\
\hline Életkor (év) & Felnőttek & $3-10$ & $3-8$ & $2-10$ & $3-10$ & $4-19$ \\
\hline Magas reszponzivitás (\%) & 5 & 33 & 36 & 48 & 56 & 2 \\
\hline Közepes reszponzivitás (\%) & 35 & 45 & 46 & 42 & 38 & 9 \\
\hline Alacsony reszponzivitás (\%) & 60 & 22 & 18 & 10 & 6 & 89 \\
\hline
\end{tabular}


roidindukált mellékhatások kialakulásának valószínûségét. Ennek elkerülése érdekében nem lehet eléggé hangsúlyozni az ellenőrző vizsgálatok fontosságát, továbbá a páciens, illetve a gyermeket otthonában kezelő szülő kellően alapos felvilágosítását.

\section{A szteroidindukált glaukóma jellemzői gyermekkorban}

Egy tanulmányban SIG-val diagnosztizált gyermekeken a megbetegedés klinikai jellegzetességeit vizsgálták. Úgy találták, hogy a kezelést leggyakrabban indikáló megbetegedés a tavaszi kötőhártya-gyulladás volt (95\%). A leggyakrabban 0,1\%-os dexametazont használtak, melyet a gyermekek közel kétharmada egy évnél hosszabb ideig alkalmazott szemcsepp formájában. Ez a tanulmány is kimutatta, hogy a szemnyomás-emelkedés leginkább tízéves kor alatti gyermekeknél jelentkezik, fóként a 4-7 éves korosztályban (41\%). A vizsgált szemek 64\%-ánál állapítottak meg vakságot (visus $\leq 0,05$ ). E tanulmány szerint tehát a kontrollálatlan, hosszú távon alkalmazott lokális DMS-kezelés SIG kialakulásához vezet, így a VKC kezelésében valamely kevésbé hatékony szer alkalmazása ajánlott, megfelelő indikáció és rendszeres ellenőrzés mellett [30]. Egy hasonló kutatásban szintén szteroidindukált glaukómás gyermekeket vizsgáltak. Többségük szintén vernalis keratoconjunctivitis miatt állt kezelés alatt. A gyerekek fele több mint 1 évig kapta a - leggyakrabban dexametazont - tartalmazó szemcseppet. Itt a gyerekek 27\%-ánál egy-, 37,3\%-ánál kétoldali vakságot állapítottak meg a vizsgálat időpontjában. A látásromlás és a vakság itt is gyakrabban jelent meg a fiatalabb gyermekeken, mint az idősebbeken. Az adatok rámutatnak arra, hogy a szteroidtartalmú szemcsepp hosszú távú használata mellett elengedhetetlen a rendszeres szemészeti vizsgálat, hiszen a szemnyomás-emelkedés korai felismerésével és a szteroidterápia megszüntetésével a maradandó károsodások megelőzhetők [31].

\section{A kortikoszteroiddal kezelt páciens követése vernalis keratoconjunctivitisben}

A gyermekkori allergiás szembetegségekben alkalmazott szteroidterápia hosszú távú követéséről szóló irodalomban leginkább a keratoconjunctivitis vernalisban szenvedő gyermekek körében végzett tanulmányok olvashatók. A betegség hosszú távú kezeléséről és a szteroidterápia kapcsán kialakuló szövődmények arányáról kevés irodalmi adat áll rendelkezésre.

A Tabbara és mtsai által végzett kutatásban súlyos VKC-ben szenvedő, átlagosan 12,2 éves gyermekeket követtek két éven át. A gyermekek 55\%-ánál alakult ki látásromlás, melynek hátterében a leggyakrabban a szteroidindukált szürke hályog állt $(25 \%)$. A SIG a gyermekek 12\%-ánál jelent meg. Azoknál a gyermekeknél, akiknél észlelték a szteroidterápia mellékhatásait, a szemor- vosi ellenőrző vizsgálatok kivétel nélkül elmaradtak. Számos fejlődő országban - köztük Szaúd-Arábiában, ahol a kutatást végezték -, a kortikoszteroidtartalmú szemcseppek recept nélkül kaphatók a gyógyszertárakban. Így azokat gyakran minden kontroll és megfelelő indikáció nélkül használják, ami hozzájárul a mellékhatások magas előfordulásához [32].

Egy hosszú távú, retrospektív vizsgálatban a szteroidreszponzivitás klinikai jellemzőit, incidenciáját és rizikófaktorait kutatták súlyos vernalis keratoconjunctivitisben szenvedő ázsiai gyermekeken. A vizsgált páciensek körében a leggyakrabban dexametazontartalmú szemcseppet alkalmaztak, melynek hatására a gyermekek 28,3\%ának emelkedett meg a szemnyomása. Glaukóma az esetek 5,5\%-ában fejlődött ki. Ebben a tanulmányban a szteroidindukált szürke hályog gyakoriságát nem mérték [33] (6. ábra).

Egy nagy esetszámú, retrospektív tanulmányban szintén a VKC komplikációit tanulmányozták. A vizsgált gyermekek fele tíz évnél fiatalabb volt. Szteroidindukált szürke hályog az esetek 1,1\%-ában, másodlagos glaukóma 0,6\%-ban jelent meg. Súlyos tavaszi kötőhártya-gyulladásban gyakori a betegség heveny fellángolása, mely szükségessé teszi a szteroid gyakori alkalmazását. A betegek gyakran több szemorvost is felkeresnek panaszaikkal, ami a kortikoszteroidok elhúzódó, kontrollálatlan használatához vezethet [34].

Az egyik legnagyobb esetszámú, VKC-ben szenvedő gyermekek körében végzett retrospektív vizsgálat szerint azoknál a gyermekeknél, akik hosszú ideig részesültek kortikoszteroidos szemcseppes kezelésben, 2,1\%-ban alakult ki SIG, míg szürke hályog csupán egy páciensnél fordult elő $(0,5 \%)$ [35]. Sofi és mtsai ugyanezeknek a szövődményeknek az arányát 3\%-nak, illetve 5\%-nak találták [36].

A rendelkezésre álló irodalmi adatok alapján a VKCben alkalmazott kortikoszteroid mellékhatásaként 0,5-

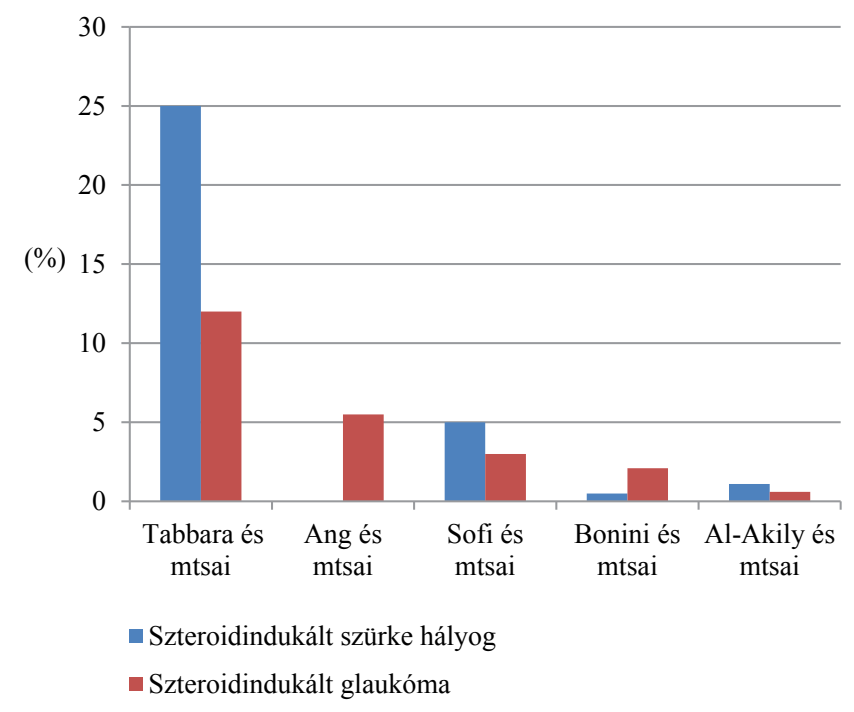

6. ábra $\quad$ A szteroidindukált szürke hályog és glaukóma gyakorisága a vizsgált tanulmányok alapján 
25\%-ban jelentkezik szürke hályog, 0,6-12\%-ban másodlagos glaukóma. Az egyes tanulmányokban a más-más arányú előfordulás adódhat a vizsgált betegek különbözô életkorából, a terápia melletti ellenőrző vizsgálatok eltérő gyakoriságából, a betegek változó együttmúködéséből. Az alkalmazott gyógyszer típusa szintén befolyásolhatja a végeredményt. A VKC kortikoszteroidterápiájában a leggyakrabban alkalmazott hatóanyagok a dexametazon, a prednizolon és a fluorometolon [37]. Az Ang és mtsai által végzett kutatáson kívül, az előzőekben leírt tanulmányokból nem derült ki, hogy milyen típusú kortikoszteroidot alkalmaztak (6. ábra).

\section{Esetbemutatás}

Az allergiás szembetegségek kezelésében hosszú távon alkalmazott kortikoszteroid súlyos mellékhatásait jól szemlélteti egy vernalis keratoconjunctivitisben szenvedő fiúgyermek esete. A gyermek hároméves volt, amikor az allergiás szemtünetei kezdődtek. Panaszaira az évek során különböző allergiaellenes, többek között kombinált készítményeket, DMS-t és tobramicint tartalmazó szemcseppet és kenőcsöt kapott, ez utóbbit a betegsége kezdete óta, éveken át. A gyermek négy évvel a kezdeti panaszokat követôen látásromlás miatt került egy magyarországi központi gyermekszemészeti ambulanciára. Ekkor már négy éve, folyamatosan fennálló allergiás szempanaszokkal küzdött, melyek kezelésére évek óta DMS-tartalmú, lokális készítményt használtak. Korrekció nélküli látásélessége a jobb szemén csupán 0,25 , a bal szemén korrekcióval 0,25 volt. A gyermek szemnyomása ekkor igen magas, 44, illetve $39 \mathrm{Hgmm}$ volt, a szemfenéken mindkét oldalon széles exkavációjú papillákat írtak le. A szteroidindukált szekunder glaukóma diagnózisa tehát egyértelmû volt. Réslámpás vizsgálattal mindkét szem hátsó kérgi cataractájára derült fény. A bal szem esetében jelentős látótér-károsodást írtak le. A szteroidterápiát ekkor felfüggesztették, kettős támadáspontú antiallergiás szert kapott, és glaukóma elleni kezelést indítottak. Ezt követôen a gyermek hamarosan ismét súlyos allergiás tünetekkel jelentkezett. Az előző vizsgálatkor beállított szerek folytatását, FLM rövid ideig tartó adagolását, valamint ciklosporin A cseppentését javasolták. Ezt követôen a gyermek allergiás szempanaszai lényegesen javultak, azonban szemnyomásértékei - a glaukómaellenes szemcseppek folyamatos használata ellenére minden vizsgálat során a normáltartományon kívül, 20 Hgmm felett voltak. A szekunder glaukóma és a szürke hályog miatt mindkét szemen mútéti beavatkozásokra volt szükség.

A gyermek kórtörténete jól példázza a nem megfelelően alkalmazott kortikoszteroidterápia veszélyes következményeit. Esetében a szteroidtartalmú szemcsepp hatására szekunder glaukóma alakult ki, mely súlyos, irreverzibilis szemfenéki elváltozásokat okozott, a szemlencsén szürke hályog jelent meg. Mindezek következtében a gyermek látásélessége nagymértékben romlott, és több szemmútétet igényelt. Ezek a beavatkozások egy gyermek számára különösen nagy megterhelést jelentenek, elsősorban pszichés szempontból, de azért is, mert invazív jellegúek, és altatással járnak. Érthetô tehát, hogy a kortikoszteroidok szemészeti alkalmazása - főleg gyermekek kezelésekor - nagy felelősséggel jár, és a kezelöorvostól fokozott elővigyázatosságot követel meg.

\section{Következtetés}

A kortikoszteroidtartalmú szemcseppek helytelen alkalmazása vissza nem fordítható következményekkel járhat. Kiemelendő, hogy a szteroidtartalmú szemcsepp szemnyomásemelő hatása gyermekeknél gyakrabban és markánsabban jelentkezik, mint felnőtteknél. A tenzióemelkedés sokáig nem okoz tüneteket. Panaszt csak a látóidegrost károsodását követő látótérkiesés okoz. Kisgyermekeknél - főleg akkor, amikor a nyelvi kifejezőkészség még nem elég fejlett - annak tüneteit igen nehéz észrevenni. Ezek miatt, tehát ebben az életkorban a kortikoszteroidterápia során a gyakori - legalább hetenkénti - szemészeti ellenőrző vizsgálat különösen fontos. A szemnyomás rendszeres mérésével, réslámpás és szemfenékvizsgálattal a végül irreverzibilis, de kezdetben még csak minimális elváltozásokat jelentő látáskárosodás időben felfedezhető, és szükség esetén a kezelésen módosítani lehet. A szteroidtartalmú készítmények elővigyázatos alkalmazásával, a hatóanyag megfelelő megválasztásával a súlyos látásromlás kialakulása megelőzhető.

Anyagi támogatás: A közlemény megírása anyagi támogatásban nem részesült.

Szerzôi munkamegosztás: Cs. A.: A szakirodalom kutatása, elemzése, az összefoglaló dolgozat megírása, szerkesztése. Sz. A., S. A., M. O., N. Z. Zs.: A kutatás tervezése, irányítása, a kézirat megszövegezése. A cikk végleges változatát valamennyi szerző elolvasta és jóváhagyta.

Érdekeltségek: A szerzőknek nincsenek érdekeltségeik.

\section{Köszönetnyilvánítás}

Az első szerző köszönetet mond $d r$. Szamosi Annának a munkája során nyújtott iránymutatásáért, továbbá $d r$. Soproni Annának önzetlen segítségéért.

\section{Irodalom}

[1] Bielory L. Allergic and immunologic disorders of the eye. Part II: Ocular allergy. J Allergy Clin Immunol. 2000; 106: 10191032 .

[2] Geraldini M, Neto HJ, Riedi CA, et al. Epidemiology of ocular allergy and co-morbidites in adolescents. J Pediatr. 2013; 89: 354-360.

[3] Schmid KL, Schmid LM. Ocular allergy: causes and therapeutic options. Clin Exp Optom. 2000; 83: 257-270. 
[4] Leonardi A, Bogacka E, Fauquert JL, et al. Ocular allergy: recognizing and diagnosing hypersensitivity disorders of the ocular surface. Allergy 2012; 67: 1327-1337.

[5] Kolozsvári L. Diseases of the conjunctiva. In: Süveges I. (ed.) Ophthalmology. [A kötőhártya (conjunctiva) betegségei. In: Süveges I. (szerk.) Szemészet.] Medicina Könyvkiadó, Budapest, 2015; pp. 106-107. [Hungarian]

[6] Friedlaender MH. Ocular allergy and immunology. J Allergy Clin Immunol. 1979; 63: 51-60.

[7] Sánchez-Hernández MC, Montero J, Rondon C, et al. Consensus document on allergic conjunctivitis (DECA). J Investig Allergol Clin Immunol. 2015; 25: 94-106.

[8] Abelson MB, Shetty S, Kochak M, et al. Advances in pharmacotherapy for allergic conjunctivitis. Expert Opin Pharmacother. 2015; 16: 1219-1231.

[9] Bielory BP, O'Brien TP, Bielory L. Management of seasonal allergic conjunctivitis: guide to therapy. Acta Ophthalmol. 2012; 90: 399-407.

[10] Ono SJ, Abelson MB. Allergic conjunctivitis: update on pathophysiology and prospects for future treatment. J Allergy Clin Immunol. 2005; 115: 118-122.

[11] O'Brien TP. Allergic conjunctivitis: an update on diagnosis and management. Curr Opin Allergy Clin Immunol. 2013; 13: 543549.

[12] Bielory BP, Perez VL, Bielory L. Treatment of seasonal allergic conjunctivitis with ophthalmic corticosteroids: in search of the perfect ocular corticosteroids in the treatment of allergic conjunctivitis. Curr Opin Allergy Clin Immunol. 2010; 10: 469477.

[13] Sheppard JD, Comstock TL, Cavet ME. Impact of the topical ophthalmic corticosteroid loteprednol etabonate on intraocular pressure. Adv Ther. 2016; 33: 532-552.

[14] Öner V, Türkcü FM, Taş M, et al. Topical loteprednol etabonate $0.5 \%$ for treatment of vernal keratoconjunctivitis: efficacy and safety. Jpn J Ophthalmol. 2012; 56: 312-318.

[15] Erdinest N, Solomon A. Topical immunomodulators in the management of allergic eye diseases. Curr Opin Allergy Clin Immunol. 2014; 14: 457-463.

[16] Kari O, Saari KM. Updates in the treatment of ocular allergies. J Asthma Allergy 2010; 3: 149-158.

[17] Wu MM, Yau GS, Lee JW, et al. Retrospective review on the use of topical cyclosporin A $0.05 \%$ for paediatric allergic conjunctivitis in Hong Kong Chinese. Sci World J. 2014; 2014: 396987.

[18] Ozcan AA, Ersoz TR, Dugler E. Management of severe allergic conjunctivitis with topical cyclosporin A $0.05 \%$ eyedrops. Cornea 2007; 26: 1035-1038.

[19] Rikkers SM, Holland GN, Drayton GE, et al. Topical tacrolimus treatment of atopic eyelid disease. Am J Ophthalmol. 2003; 135: 297-302.

[20] Costa AX, Gomes JÁ, Marculino LG, et al. Supratarsal injection of triamcinolone for severe vernal keratoconjunctivitis in children. Arq Bras Oftalmol. 2017; 80: 186-188.
[21] Jiang D, Zhang M, Hu Y. Resection and cryotherapy combined with amniotic membrane transplantation for the treatment of vernal keratoconjunctivitis with giant papillae. J Huazhong Univ Sci Technolog Med Sci. 2006; 26: 618-620.

[22] Leonardi A. Management of vernal keratoconjunctivitis. Ophthalmol Ther. $2013 ; 2: 73-88$.

[23] Lam DS, Fan DS, Ng JS, et al. Ocular hypertensive and anti-inflammatory responses to different dosages of topical dexamethasone in children: a randomized trial. Clin Exp Ophthalmol. 2005; 33: 252-258.

[24] Razeghinejad MR, Katz LJ. Steroid-induced iatrogenic glaucoma. Ophthalmic Res. 2012; 47: 66-80.

[25] Akingbehin AO. Comparative study of the intraocular pressure effects of fluorometholone $0.1 \%$ versus dexamethasone $0.1 \%$. $\mathrm{Br}$ J Ophthalmol. 1983; 67: 661-663.

[26] Ohji M, Kinoshita S, Ohmi E, et al. Marked intraocular pressure response to installation of corticosteroids in children. Am J Ophthalmol. 1991; 112: 450-454.

[27] Ng JS, Fan DS, Young AL, et al. Ocular hypertensive response to topical dexamethasone in children: a dose-dependent phenomenon. Ophthalmology 2000; 107: 2097-2100.

[28] Kwok AK, Lam DS, Ng JS. Ocular-hypertensive response to topical steroids in children. Ophthalmology 1997; 104: 21122116.

[29] Brookes JL, Khaw PT. Steroid response in children. Clin Exp Ophthalmol. 2005; 33: 229-230.

[30] Badriyah IN, Irfani I, Rakhmilla LE. Characteristics of childhood steroid-induced glaucoma patients in National Eye Center, Cicendo Eye Hospital, Bandung, Indonesia from 2007 to 2011. Althea Med J. 2015; 2: 346-351.

[31] Gupta S, Shah P, Grewal S, et al. Steroid-induced glaucoma and childhood blindness. Br J Ophthalmol. 2015; 99: 1454-1456.

[32] Tabbara KF. Ocular complications of vernal keratoconjunctivitis. Can J Ophthalmol. 1999; 34: 88-92.

[33] Ang M, Ti SE, Loh R, et al. Steroid-induced ocular hypertension in Asian children with severe vernal keratoconjunctivitis. Clin Ophthalmol. 2012; 6: 1253-1258.

[34] Al-Akily SA, Bamashmus MA. Ocular complications of severe vernal keratoconjunctivitis (VKC) in Yemen. Saudi J Ophthalmol. 2011; 25: 291-294.

[35] Bonini S, Bonini S, Lambiase A, et al. Vernal keratoconjunctivitis revisited: a case series of 195 patients with long-term followup. Ophthalmology 2000; 107: 1157-1163.

[36] Sofi RA, Mufti A. Vernal keratoconjunctivitis in Kashmir: a temperate zone. Int Ophthalmol. 2016; 36: 875-879.

[37] Vichyanond P, Pacharn P, Pleyer U, et al. Vernal keratoconjunctivitis: a severe allergic eye disease with remodeling changes. Pediatr Allergy Immunol. 2014; 25: 314-322.

(Csorba Anita dr., Budapest, Mária u. 39., 1085 e-mail: csorbani@gmail.com)

A cikk a Creative Commons Attribution 4.0 International License (https://creativecommons.org/licenses/by/4.0/) feltételei szerint publikált Open Access közlemény, melynek szellemében a cikk bármilyen médiumban szabadon felhasználható, megosztható és újraközölhető, feltéve, hogy az eredeti szerző és a közlés helye, illetve a CC License linkje és az esetlegesen végrehajtott módosítások feltüntetésre kerülnek. (SID_1) 